$\begin{array}{ll}\text { Research Square } & \begin{array}{l}\text { Preprints are preliminary reports that have not undergone peer review. } \\ \text { They should not be considered conclusive, used to inform clinical practice, } \\ \text { or referenced by the media as validated information. }\end{array}\end{array}$

\title{
Impact of COVID-19 confinement on the time and intensity of physical activity in the Spanish population
}

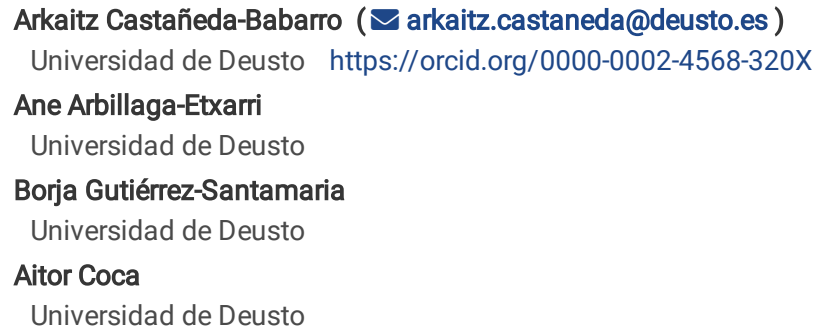

\section{Research}

Keywords: confinement, physical activity, sedentary behaviour, Covid-19

Posted Date: May 6th, 2020

DOl: https://doi.org/10.21203/rs.3.rs-26074/v1

License: (c) (i) This work is licensed under a Creative Commons Attribution 4.0 International License. Read Full License 


\section{Abstract \\ Background}

The lockdown and social distancing caused by COVID-19 may influence common healthy behaviour. Due to the unprecedent worldwide confinement in which Spain has been one of the most affected with severe rules governing confinement, physical activity and sedentarism may change due to prolonged stays at home. The aim of this study is to evaluate how physical activity and sedentary time have changed during confinement in the Spanish population.

\section{Methods}

3800 healthy adults (age $\geq 18$ - $\leq 64$ years) residing in Spain were asked during confinement. Sociodemographic data and self-reported physical activity data were collected twice by an International Physical Activity Questionnaire-Short (IPAQ-S) between 23rd March and 1st April, and the analysis was carried out considering the achievement of general physical activity recommendations, different age ranges and baseline physical activity levels.

\section{Results}

Physical activity decreased significantly during confinement in all population. Vigorous activities and walking time decreased by $16.8 \%(\mathrm{p}$-value $>0.001)$ and $58.2 \%$ ( $p$-value $>0.001$ ) respectively, whereas sedentary time increased by $23.8 \%$ ( $p$-value $>0.001)$. The fulfilment of $75 \mathrm{~min} /$ week of vigorous activity recommendation decreased by $10.7 \%$ ( $p$-value $<0.001$ ) while the amount of people who reached to $150 \mathrm{~min} /$ week of moderate activity barely changed $(1.4 \%$, (p-value 0.117$)$ ). The group that performed more vigorous physical activities before confinement showed the greatest decrease $(30.5 \%, p$-value $>0.001)$. Men reduced more the time in vigorous activity than women ( $21 \%$ vs $9 \%$, respectively) who even increased time in moderate physical activity by $11 \%$ ( $\mathrm{p}$-value < 0.05 ) and showed less increase in sitting time than men ( $35 \%$ vs $25.3 \%$, respectively). Young people and students showed the highest decrease in all physical activities.

\section{Conclusions}

The Spanish adult population, especially young people, students and very active men, decreased daily physical activity and increased sedentary time during COVID-19 confinement.

\section{Background}

On 11th March 2020, the World Health Organization (WHO) (1) declared a global pandemic caused by SARS-Covid-2 virus, which has become a public health emergency of international concern.

The Coronavirus disease (COVID-19) outbreak in Spain has already had a direct impact on more than 46 million people. The Spanish Government declared a state of emergency on 17th March and ordered a lockdown, to restrict travel and cancel non-essential services in order to stop the spread of COVID-19 (2).

Social distancing and confinement are fundamental in tackling the spread of coronavirus. However, the ongoing lockdown across the country has no precedent and it is unknown how that may affect the general population's health and wellbeing. In these circumstances, the sudden and stressful situation in addition to the prolonged stays at home may imply a radical change in lifestyle behaviour such as physical activity, eating habits, alcohol consumption, mental health, quality of sleep, and so on (3-7).

Likewise, there is significant concern about physical activity and sedentary behaviour (8). Due to isolation and limitation in engaging in regular, common activities, COVID-19 has radically modified the determining factors (individual, interpersonal, environmental, regional or national policies and global) (9) of both types of behaviour. Therefore, taking into account the general recommendations for physical activity in adults (at least 150 minutes of moderate or 75 minutes of vigorous intensity activity a week, or a combination of both) (10), the unprecedented confinement situation may give rise to two situations of concern to health whereby sedentary behaviour will increase because 1) the active population may decrease their activity and 2) the inactive population may not be likely to increase their daily physical activity.

Therefore, the aim of this study was to analyse physical activity and sedentary behaviour before and during COVID-19 in a Spanish healthy adult population.

\section{Methods}

Healthy adults (age $\geq 18$ - $\leq 64$ years) living in Spain were asked to participate in this cross-sectional study. Sociodemographic and self-reported physical activity data were asked twice by questionnaire between 23rd March and 1st April, just the week after the state of emergency was declared in Spain and over the following two weeks. The invitation to participate in the study was issued through social media, e-mail and mobile phone from the Physical Activity and Sports Sciences Department, University of Deusto. Moreover, a national sports store (Forumsport S.A.) and a Biomechanical Laboratory (Custom4us) also sent the questionnaire to their customers by e-mail. Ethics approval was obtained from the Deusto University Human Ethics Advisory Group. Informed consent was obtained from participants.

Sociodemographic data (age, height, weight, sex, whether working and/or studying) and self-reported physical activity was requested twice, one week before and one or two weeks since confinement started, by the IPAQ-S validated in Spanish (11). The IPAQ-S asked about three specific types of activity undertaken 
during the previous 7 days in the four domains (leisure time, work, household activities and transport), and items were structured to provide separate scores for walking, moderately intense and vigorously intense activities. The IPAQ also contained a question to identify the time spent on sedentary activity.

The primary outcome was the change in time and intensity of physical activity and the sedentary time from prior to the confinement situation and after it. The secondary outcome was the change in the percentage number of participants who fulfilled general physical activity recommendations according to age, gender, working status and baseline physical activity levels.

4160 healthy subjects answered the questionnaire, although 360 were not included due to exclusion criteria: not resident in Spain, age $\geq 65$ and extreme scores in vigorous, moderate and walking activities ( $\geq 6$ hours per day 7 days a week).

\section{Data analysis}

A univariate analysis with paired t-tests was used to compare the differences in primary and secondary outcomes before and during confinement. A Chi ${ }^{2}$ frequency test was used to assess differences in the amount of physical activity between groups. The subgroup analysis was performed by groups of different ages ( $18-\leq 24 ;>25-\leq 34 ;>35-\leq 44 ;>45-\leq 54 ;>55-\leq 64)$, gender, working status (students, active workers, people that study and work, and those that reported they did nothing), and physical activity categorized by the following four groups for vigorous activity groups 0 to $\leq 75,>75$ to $\leq 150,>150$ to $\leq$ $225,>225 \mathrm{~min} /$ week, and 0,0 to $\leq 150,>150$ to $\leq 300,>300$ to $\leq 450,>450 \mathrm{~min} /$ week for moderate activity. Statistical analysis was performed using the SPSS Data Analysis Version 23 (SPSS Inc.,Chicago, IL).

\section{Results}

Table 1 shows the demographic characteristics of 3800 participants who were mostly male, (54\%) active workers (78\%) and age $42.7 \pm 10.4$ years (mean \pm $\mathrm{SD})$.

Table 1

Demographic characteristics of 3800 healthy subjects before confinement.

\begin{tabular}{|ll|}
\hline \multicolumn{2}{|c}{$\mathrm{n}=\mathbf{3 8 0 0}$} \\
\hline \multicolumn{2}{|l}{ Before confinement } \\
\hline Age year & $42.7 \pm 10.4$ \\
\hline Height cm & $171 \pm 8$ \\
\hline Weight Kg & $71 \pm 12$ \\
\hline Male / Female & $2054(54) / 1746(46)$ \\
\hline Workers & $2956(78)$ \\
\hline Students & $267(7)$ \\
\hline Study-Work & $374(10)$ \\
\hline Nothing & $203(5)$ \\
\hline Data are presented as mean \pm SD, $\mathrm{n}(\%)$ \\
\hline
\end{tabular}

During confinement, the amount of time spent on moderate and vigorous activities by all the population decreased by $2.6 \%$ ( $p$-value 0.102$)$ and $16.8 \%$ ( $p$ value $>0.001)$ respectively. In addition, walking time was reduced by $58.2 \%$ ( $p$-value $>0.001)$ whereas sedentary time increased by $23.8 \%$ ( $p$-value $>0.001)$ (Table 2). 
Table 2

Physical activity data before and during confinement in all the population and different subgroups.

\begin{tabular}{|c|c|c|c|c|c|c|c|c|c|c|}
\hline $\begin{array}{l}\text { SUBGROUP } \\
\text { ANALYSIS }\end{array}$ & $\begin{array}{l}\text { Before } \\
\text { confinement }\end{array}$ & $\begin{array}{l}\text { During } \\
\text { confinement }\end{array}$ & $\begin{array}{l}\text { p- } \\
\text { value }\end{array}$ & $\begin{array}{l}\text { Before } \\
\text { confinement }\end{array}$ & $\begin{array}{l}\text { During } \\
\text { confinement }\end{array}$ & $\begin{array}{l}\mathrm{p}- \\
\text { value }\end{array}$ & $\begin{array}{l}\text { Before } \\
\text { confinement }\end{array}$ & $\begin{array}{l}\text { During } \\
\text { confinement }\end{array}$ & $\begin{array}{l}\mathrm{p}- \\
\text { value }\end{array}$ & $\begin{array}{l}\text { Before } \\
\text { confin }\end{array}$ \\
\hline & \multicolumn{3}{|c|}{ Time in vigorous activities } & \multicolumn{3}{|c|}{ Time in moderate activities } & \multicolumn{3}{|l|}{ Walking time } & Sitting \\
\hline $\begin{array}{l}\text { Total }(n= \\
3800)\end{array}$ & $219 \pm 196$ & $182 \pm 184$ & $<.001$ & $149 \pm 174$ & $145 \pm 170$ & 0.102 & $282 \pm 253$ & $116 \pm 189.3$ & $<.001$ & $\begin{array}{l}(n=36 \\
6.1 \pm 3\end{array}$ \\
\hline $\begin{array}{l}\text { Women }(n \\
=1746)\end{array}$ & $175 \pm 176$ & $159 \pm 174$ & $<.001$ & $133 \pm 160$ & $144 \pm 159$ & $\dot{0} 05$ & $302 \pm 260$ & $122 \pm 199.3$ & $<.001$ & $\begin{array}{l}(n=16 \\
6.3 \pm 3\end{array}$ \\
\hline $\begin{array}{l}\text { Men }(n= \\
2054)\end{array}$ & $256 \pm 204$ & $202 \pm 190$ & $<.001$ & $163 \pm 185$ & $145 \pm 179$ & $<001$ & $265 \pm 247$ & $110 \pm 180.1$ & $<.001$ & $\begin{array}{l}(n=19 \\
\pm 3.1\end{array}$ \\
\hline $\begin{array}{l}\text { Workers ( } \mathrm{n} \\
=2956)\end{array}$ & $\begin{array}{l}212.1 \pm \\
189.9\end{array}$ & $\begin{array}{l}177.3 \pm \\
179.4\end{array}$ & $\dot{0} 001$ & $\begin{array}{l}143 \pm \\
169.17\end{array}$ & $\begin{array}{l}142.2 \pm \\
170.6\end{array}$ & 0.811 & $\begin{array}{l}269.3 \pm \\
246.2\end{array}$ & $\begin{array}{l}113.70 \pm \\
182.7\end{array}$ & $\dot{0} 001$ & $\begin{array}{l}(n=28 \\
6.2 \pm 3\end{array}$ \\
\hline $\begin{array}{l}\text { Students } \\
(\mathrm{n}=267)\end{array}$ & $\begin{array}{l}295.5 \pm \\
221.0\end{array}$ & $\begin{array}{l}223.7 \pm \\
199.1\end{array}$ & $<.001$ & $\begin{array}{l}171.1 \pm \\
191.8\end{array}$ & $\begin{array}{l}143.5 \pm \\
157.1\end{array}$ & $\begin{array}{l}< \\
0.05\end{array}$ & $\begin{array}{l}298.8 \pm \\
246.1\end{array}$ & $98.8 \pm 189.7$ & $\begin{array}{l}<.001 \\
0.00\end{array}$ & $\begin{array}{l}(n=26 \\
6.4 \pm 2\end{array}$ \\
\hline $\begin{array}{l}\text { Study-Work } \\
(n=374)\end{array}$ & $\begin{array}{l}223.6 \pm \\
196.8\end{array}$ & $\begin{array}{l}193.2 \pm \\
195.2\end{array}$ & $\begin{array}{l}<.001 \\
0.00\end{array}$ & $\begin{array}{l}157.4 \pm \\
177.1\end{array}$ & $144 \pm 160.6$ & 0.141 & $\begin{array}{l}301.3 \pm \\
249.5\end{array}$ & $\begin{array}{l}106.1 \pm \\
179.6\end{array}$ & $\dot{0} 001$ & $\begin{array}{l}(n=36 \\
6.3 \pm 4\end{array}$ \\
\hline $\begin{array}{l}\text { Nothing (n } \\
=203 \text { ) }\end{array}$ & $\begin{array}{l}213.9 \pm \\
228.4\end{array}$ & $\begin{array}{l}179.6 \pm \\
201.1\end{array}$ & 0.013 & $198 \pm 208.8$ & $\begin{array}{l}184.6 \pm \\
190.4\end{array}$ & 0.316 & $\begin{array}{l}403.3 \pm \\
326.3\end{array}$ & $\begin{array}{l}186.6 \pm \\
267.2\end{array}$ & $\begin{array}{l}< \\
0.001\end{array}$ & $\begin{array}{l}(n=19 \\
4.4 \pm 2\end{array}$ \\
\hline
\end{tabular}

Age

categories

\begin{tabular}{|c|c|c|c|c|c|c|c|c|c|c|}
\hline $\begin{array}{l}18-\leq 24(n \\
=264)\end{array}$ & $300 \pm 206.6$ & $246 \pm 189.1$ & $\begin{array}{l}< \\
0.001\end{array}$ & $180 \pm 197.3$ & $149 \pm 154.6$ & $\begin{array}{l}<.05 \\
0.05\end{array}$ & $321 \pm 281.8$ & $94 \pm 182.6$ & $\begin{array}{l}< \\
0.001\end{array}$ & $\begin{array}{l}(n=25 \\
6.6 \pm 4\end{array}$ \\
\hline $\begin{array}{l}\geq 25-\leq 34 \\
(n=670)\end{array}$ & $244 \pm 197.9$ & $201 \pm 193.6$ & $\begin{array}{l}< \\
0.001\end{array}$ & $139 \pm 150.3$ & $145 \pm 159.4$ & 0.345 & $280 \pm 244.2$ & $97 \pm 161.1$ & $\begin{array}{l}< \\
0.001\end{array}$ & $\begin{array}{l}(n=65 \\
6.4 \pm 3\end{array}$ \\
\hline $\begin{array}{l}\geq 35-\leq 44 \\
(n=1361)\end{array}$ & $209 \pm 189.9$ & $175 \pm 174.5$ & $\begin{array}{l}<.001 \\
0.001\end{array}$ & $141 \pm 176.6$ & $140 \pm 173.5$ & 0.830 & $253 \pm 235.8$ & $108 \pm 186.8$ & $\begin{array}{l}< \\
0.001\end{array}$ & $\begin{array}{l}(n=13 \\
\pm 3.9\end{array}$ \\
\hline $\begin{array}{l}\geq 45-\leq 54 \\
(n=1158)\end{array}$ & $202 \pm 184.4$ & $171 \pm 183.3$ & $\begin{array}{l}< \\
0.001\end{array}$ & $150 \pm 172.7$ & $142 \pm 170.7$ & 0.121 & $285 \pm 256.1$ & $125 \pm 197.8$ & $\begin{array}{l}< \\
0.001\end{array}$ & $\begin{array}{l}(n=11 \\
6.1 \pm 3\end{array}$ \\
\hline $\begin{array}{l}\geq 55-<65 \\
(n=347)\end{array}$ & $199 \pm 126$ & $155 \pm 186.1$ & $\begin{array}{l}<.001 \\
0.00\end{array}$ & $169 \pm 191.7$ & $162 \pm 184.3$ & 0.405 & $354 \pm 284.1$ & $160 \pm 213.2$ & $\begin{array}{l}< \\
0.001\end{array}$ & $\begin{array}{l}(n=33 \\
5.7 \pm 3\end{array}$ \\
\hline
\end{tabular}

PA

categories

\begin{tabular}{|c|c|c|c|c|c|c|c|c|c|c|}
\hline $\begin{array}{l}0-\leq 75(\mathrm{n} \\
=962)\end{array}$ & $16 \pm 23.7$ & $71 \pm 124.7$ & $\begin{array}{l}<.001 \\
0.001\end{array}$ & $101 \pm 138.1$ & $127 \pm 153.9$ & $\begin{array}{l}<.001 \\
0.001\end{array}$ & $291 \pm 269.1$ & $127 \pm 211.8$ & $<.001$ & $\begin{array}{l}(n=93 \\
6.4 \pm 3\end{array}$ \\
\hline $\begin{array}{l}>75-\leq 150 \\
(n=711)\end{array}$ & $115 \pm 21.6$ & $125 \pm 116.2$ & $\begin{array}{l}<.05 \\
0.05\end{array}$ & $119 \pm 120.9$ & $121 \pm 132.8$ & 0.596 & $248 \pm 219.5$ & $93 \pm 155.7$ & $<.001$ & $\begin{array}{l}(n=69 \\
6.5 \pm 4\end{array}$ \\
\hline $\begin{array}{l}>150- \\
\leq 225(n= \\
550)\end{array}$ & $188 \pm 16.4$ & $172 \pm 134.2$ & $\begin{array}{l}< \\
0.01\end{array}$ & $136 \pm 146$ & $128 \pm 156.6$ & 0.231 & $256 \pm 226.2$ & $93 \pm 153.8$ & $\begin{array}{l}< \\
0.001\end{array}$ & $\begin{array}{l}(n=52 \\
6.2 \pm 3\end{array}$ \\
\hline $\begin{array}{l}>225(n= \\
1577)\end{array}$ & $400 \pm 170.7$ & $278 \pm 203$ & $\begin{array}{l}< \\
0.001\end{array}$ & $196 \pm 208$ & $171 \pm 193.7$ & $\begin{array}{l}< \\
0.001\end{array}$ & $299 \pm 264.1$ & $126 \pm 197.5$ & $\begin{array}{l}< \\
0.001\end{array}$ & $\begin{array}{l}(n=15 \\
5.7 \pm 3\end{array}$ \\
\hline
\end{tabular}

Data are presented as $n$, mean \pm SD. *Some variables pertaining to sedentary time have missing values, as follows: Total $(n=113)$; Women $(n=52)$; Men $(n=$ $(n=5)$; Study-Work $(n=13)$; Nothing $(n=4)$;

Age categories $18-\leq 24(n=6) ; \geq 25-\leq 34(n=15) ; \geq 35-\leq 44(n=38) ; \geq 45-\leq 54(n=45) ; \geq 55-<65(n=9) ;$ PA categories $0-\leq 75(n=25) ;>75-\leq 150(n=13$ $(n=53)$.

Regarding fulfilment of physical activity recommendations, the number of subjects who failed to complete 75 minutes of vigorous intensity per week before confinement increased by $10.7 \%$ ( $p$-value < 0.001 ) during lockdown. (Table 3 ). In addition, the most active population (>225 min/week of vigorous activity) decreased their activity significantly by $7.7 \%$ ( $p$-value $<0.001)$. Nevertheless, fulfilment of 150 minutes of moderate activity per week barely changed $(1.4 \%$, $p$ value 0.117 ). 
Table 3

Subgroup analysis in different ranges of physical activity levels

\begin{tabular}{|llll|}
\hline \multicolumn{4}{|c|}{ before and during COVID-19. } \\
\hline $\begin{array}{l}\text { Subgroup categories } \\
\text { (time; min/week) }\end{array}$ & $\begin{array}{l}\text { Before } \\
\text { confinement }\end{array}$ & $\begin{array}{l}\text { During } \\
\text { confinement }\end{array}$ & p-value \\
\hline Vigorous activity & & & \\
\hline $0-\leq 75$ & $962(25.3 \%)$ & $1369(36 \%)$ & $<0.001$ \\
\hline$>75-\leq 150$ & $711(18.7 \%)$ & $650(17.1 \%)$ & 0.068 \\
\hline$>150-\leq 225$ & $550(14.5 \%)$ & $495(13 \%)$ & 0.066 \\
\hline$>225$ & $1577(41.5 \%)$ & $1286(33.8 \%)$ & $<0.001$ \\
\hline Moderate activity & & & \\
\hline $0-\leq 150$ & $2453(64.6 \%)$ & $2509(66 \%)$ & 0.117 \\
\hline$>150-\leq 300$ & $837(22 \%)$ & $776(20.4 \%)$ & 0.087 \\
\hline$>300-\leq 450$ & $274(7.2 \%)$ & $329(8.7 \%)$ & $<0.05$ \\
\hline$>450$ & $236(6 \%)$ & $186(4.9 \%)$ & $<0.05$ \\
\hline Data are presented as $\mathrm{n}(\%)$ & & \\
\hline
\end{tabular}

In the subgroup analysis, the most active subjects showed the highest decrease in vigorous activity time (30.5\%, p-value < 0.001$)($ Table 2$)$. However, the less active population increased the time they spent on these activities by $34 \%$ and this trend is also evidenced in the case of moderate activities. Furthermore, walking time declined similarly for all physical activity levels, while in terms of sedentary time the most active group showed the highest increase (40.3\%, $\mathrm{p}$ value $<0.001)$.

Men showed a higher decrease in vigorous activities than women ( $21 \%$ and $9 \%$, respectively) and both reduced walking time to a similar extent ( $58.5 \%$ men, $59.6 \%$ women) (Table 2). However, sedentary time showed a higher increase in men (35\%, p-value $<0.001)$ than in women $(25.3 \%$, $p$-value $<0.001)$ and accordingly, men significantly reduced moderate activities by $8.2 \%$ ( $\mathrm{p}$-value $<0.001)$ while women increased these activities by $11 \%(\mathrm{p}$-value $<0.05)$.

The students' group showed the highest decrease in moderate (16.1\% p-value 0.05$)$, vigorous (24.3\%, p-value 0.001$)$ and walking activities (66.9\% p-value 0.001 ), whereas unemployed or non-students were the most sedentary during confinement $(47.7, \mathrm{p}$-value $<0.001)($ Table 2$)$. The adult population (age $\geq 55$ $<65$ years) decreased the amount of time they spent on vigorous activities the most (22,1\%) whereas for moderate activities and walking time it was the youngest subjects (18 - $\leq 24$ years) who also evidenced the greatest increase in sedentary time (47.7\% p-value 0.001$)$.

\section{Discussion}

Physical activity decreased significantly during confinement in all the population where vigorous and walking activities declined the most and moderate activities barely changed. There were more inactive people who failed to fulfil the $75 \mathrm{~min} /$ week of vigorous activities during lockdown, and sedentary time also increased considerably. The impact on active and sedentary behaviour was particularly high in men, young people, students and the physically very active population.

To our knowledge, there are no previous studies that have analysed the effect of confinement caused by a pandemic on physical activity. Thus, it is difficult to assess whether the population we studied has reduced the amount of physical activity to a smaller or larger extent. The only available data we found about physical activity during confinement comes from an activity tracker, where it has been shown that in Europe the country with the greatest step count decrease recorded was Spain, with $38 \%$ less, followed by Italy with $25 \%$. This reduction is similar to the falling trend in walking time shown in our study. In this regard, other studies carried out in similar lockdown situations (confinement during seasons with adverse weather conditions - cold winter or heat waves) also reported physical activity decrease during confinement, whereas sedentary time increases because poor or extreme weather becomes an environmental barrier to going outdoors (13-16).

Sedentary time increased considerably, most likely due to the exchange between common daily active behaviour (walking, cycling or transport to work, etc.) and the prolonged stay at home. Young people and students spend more time seated during confinement and this may be due to the forced e-learning which encourages sedentary behaviour related to excessive time in screen-based activities (17). Likewise, according to the socio-ecological model (9), in a comparable framework where social or environmental barriers promote an inactive lifestyle (social isolation, loneliness and, when season changes) have been reported more sedentary behaviour and less time being spent on light, moderate and vigorous physical activities (18-20). Hence, an involuntary prolonged stay at home may encourage sedentary behaviour as well as during confinement caused by COVID-19.

The most active subjects showed the highest decrease in vigorous activity time and this may be explained by two main reasons: the forced sudden inaccessibility to community resources (e.g. sports facilities, urban trails, parks, green spaces, etc.) and the lack of time to react during the first weeks of confinement to gather fitness resources in order to continue engaging in regular activities at home. 
Regarding moderate activities, our data showed that it barely changed in all the population and this could be attributed to the fact that some people might have been maintaining the minimum recommended time doing alternative activities at home. In this regard, the less active population increased vigorous and moderate activities during confinement and that could be related to the promotion of such activities by health institutions, fitness centres, the Internet and television by posting daily online workout routines. Thus, there are people that have found new ways of being more active during this lockdown.

Active behaviour changed according to gender. Both genders reduced walking time to a similar extent, although men showed a higher decrease in vigorous activities that may be related to the greater physical inactivity prevalence reported in women over the years. (21-24). According to sedentary behaviour, sitting time showed a higher increase in men who also significantly reduced moderate activities while women increased these activities. This could be attributed to the gender gap by historically proven female inequality in household and child care tasks, in which where men have shown a low level of involvement in Spain (25-27).

Regarding fulfilment of physical activity recommendations, the global age-standardized prevalence among the non-active population was $27.5 \%$ in 2016 (22). According to the Eurobarometer (Eurobarometer, 2014), 33.6\% of the Spanish adult population did not attain minimum levels of physical activity, and 36\% spent most of the day sitting down (National Health Surveys in Spain, n.d.). In our population, our inactive population before confinement is lower (25.3\% according to $75 \mathrm{~min} /$ week vigorous physical activity) in comparison to Eurobarometer. That may be explained by the fact that the population recruited for the study was particularly more active as shown in the data for people undertaking $>225 \mathrm{~min} /$ week of vigorous activities, and this could be attributed to the fact that the questionnaire was shared by institutions related to sport, exercise and biomechanics. Therefore, it is to be expected that we recruited a population that is commonly more active than the general population.

A limitation of the current study is that we selected the IPAQ- Short version instead of the IPAQ-Long one because of concerns that the length of the questionnaire would result in significant participant burden. In addition, although the questionnaire collects data about the last 7 days, in our study we requested information beyond a week, which may be justified due to the unprecedented situation and the lack of time available to manage more appropriate study design and methods. Another limitation would be the cross-sectional design of the study, since directionality of the associations cannot be established.

On the other hand, one of the strengths of the study is that the questionnaire was sent just when the population started confinement (during the first two weeks), so it is likely the participants had their common activities in mind before confinement in a fresh and realistic form. To our knowledge, this is the first study carried out on a confined large sample size, which may be useful in designing different strategies in order to reduce sedentarism and increase physical activity by the confined population.

\section{Conclusions}

In conclusion, healthy adults reduced daily physical activity and increased sedentary time during COVID-19 confinement in Spain. The impact was particularly high in men, young people, students and the very active population. Strategies should be employed to increase physical activity and decrease sedentary behaviour.

\section{Abbreviations}

WHO

World Health Organization

COVID

Coronavirus Disease

IPAQ

International Physical Activity Questionnaire

\section{Declarations}

\section{Ethics approval and consent to participate}

Ethics approval was obtained from the Deusto University Human Ethics Advisory Group. Informed consent was obtained from participants.

\section{Consent for publication}

Not applicable

\section{Availability of data and materials}

The datasets used and/or analysed during the current study are available from the corresponding author on reasonable request.

\section{Competing interests}

The authors declare that they have no competing interests 


\section{Funding}

Not applicable

\section{Authors' contributions}

ACB designed the study and ACB and AAE provided substantial contributions in writing the manuscript. ACB, BG and AC had full access to the data and carried out statistical analysis. All authors read and approved the final manuscript.

\section{Acknowledgements}

The authors gratefully acknowledge those who participated in this study and ForumSport and Custom4us for helping to disseminate the questionnaire.

\section{References}

1. WHO director media briefing on covid-19 [Internet]. 2020. Available from: https://www.who.int/dg/speeches/detail/who-director-general-s-openingremarks-at-the-media-briefing-on-covid-19--11-march-2020.

2. Spanish Royal Decree 463/2020, 14 March [Internet]. 2020. Available from: https://www.boe.es/buscar/act.php?id=BOE-A-2020$3692 \& \mathrm{p}=20200411 \& \mathrm{tn}=2$.

3. Clay JM, Parker MO. Alcohol use and misuse during the COVID-19 pandemic: a potential public health crisis? Lancet Public Heal. 2020.

4. Yanovski JA, Yanovski SZ, Sovik KN, Nguyen TT, O’Neil PM, Sebring NG. A prospective study of holiday weight gain. N Engl J Med. 2000;12:861-7.

5. Who Mental Health. Mental health and psychosocial considerations during the COVID-19 outbreak [Internet]. 2020. Available from: https://www.who.int/docs/default-source/coronaviruse/mental-health-considerations.pdf.

6. Altena E, Baglioni C, Espie CA, Ellis J, Gavriloff D, Holzinger B, Schlarb A, et al. Dealing with sleep problems during home confinement due to the COVID-19 outbreak: practical recommendations from a task force of the European CBT-I Academy. J Sleep Res. 2020.

7. Jiménez-Pavón D. AC-B and CJL. Physical exercise as therapy to fight against themental and physical consequences of COVID-19 quarantine: Special focus in older people. Prog Cardiovasc Dis. 2020.

8. Hall G, Laddu DR, Phillips SA, et al. A tale of two pandemics: How will COVID-19 and global trends in physical inactivity and sedentary behavior affect one another? Prog Cardiovasc Dis. 2020.

9. Bauman AE, Reis RS, Sallis JF, Wells JC, Loos RJF, Martin BW, et al. Correlates of physical activity: Why are some people physically active and others not? Lancet. 2012;380(9838):258-71.

10. WHO. Global recommendations on physical activity for health [Internet]. 2010. Available from:

https://www.who.int/dietphysicalactivity/publications/9789241599979/en/.

11. Wolin KY, Heil DP, Askew S, Matthews CE, Bennett GG. Validation of the International Physical Activity Questionnaire-Short Among blacks. 2008;5(5).

12. fitbit.com [Internet]. 2020. Available from: https://blog.fitbit.com/covid-19-global-activity.

13. P.Tucker JG. The effect of season and weather on physical activity: A systematic review. Public Health. 2007;121:909-22.

14. Jones GR, Brandon CGD. Physical activity levels of community-dwelling older adults are influenced by winter weather variables. Arch Gerontol Geriatr. 2017;71:28-33.

15. Nakashima D, Kimura D, Watanabe H, Goto F, Kato M, Fujii K, et al. Influence of seasonal variations on physical activity in older people living in mountainous agricultural areas. J Rural Med. 2019;14(2):165-75.

16. Arnardottir NY, Oskarsdottir ND, Brychta RJ, Koster A, van Domelen DR, Caserotti P, et al. Comparison of Summer and Winter Objectively Measured Physical Activity and Sedentary Behavior in Older Adults: Age, Gene/Environment Susceptibility Reykjavik Study. Public Health. 2017;14(10).

17. Chen. Coronavirus disease (COVID-19): The need to maintain regular physical activity while taking precautions. J Sport Heal Sci. 2020;9(2):103-4.

18. Schrempft S, Jackowska M, Hamer MSA. Associations between social isolation, loneliness, and objective physical activity in older men and women. BMC Public Health. 2019;19(1):74.

19. Kobayashi LCSA. Social Isolation, Loneliness, and Health Behaviors at Older Ages: Longitudinal Cohort Study. Ann Behav Med. 2018;52(7):582-93.

20. Hawkley LC, Thisted RACJ. Loneliness predicts reduced physical activity: cross-sectional \& longitudinal analyses. Heal Psychol. 2009;28:354-63.

21. Mayo X, Liguori G, Iglesias-Soler E, Copeland RJ, Clavel San Emeterio I, Lowe A, et al. The active living gender's gap challenge: 2013-2017 Eurobarometers physical inactivity data show constant higher prevalence in women with no progress towards global reduction goals. BMC Public Health. 2019;19(1):1677.

22. $10.1016 / \mathrm{S} 2214-109 \times(18) 30357-7$

Guthold R, Stevens GA, Riley LM, Bull FC. Worldwide trends in insufficient physical activity from 2001 to 2016 : a pooled analysis of 358 population-based surveys with 1.9 million participants. Lancet Glob Heal [Internet]. 2018;6(10):1077-86. Available from: http://dx.doi.org/10.1016/S2214-109X(18)303577.

23. Guthold R, Ono T, Strong KL, Chatteri SMA. Worldwide variability in physical inactivity a 51-country survey. Am J Prev Med. 2008;34:486-94.

24. Mielke GI, da Silva ICM, Kolbe-Alexander TLBW. Shifting the physical inactivity curve worldwide by closing the gender gap. Sport Med. 2018;48:481-9. 
25. Goldscheider F, Bernhardt EL. The gender revolution:a framework for understanding changing family and demographic behavior. Popul Dev Rev. 2015;41:207-39.

26. M. D-F. Parentalidad y división del trabajo doméstico en España, 2002-2010. Rev Española Investig Sociológicas. 2015;149:45-62.

27. García-Calvente MM, Mateo-Rodríguez I, M-NG. El impacto de cuidar en la salud y la calidad de vida de las mujeres. Gac Sanit. 2004;18:83-92. 